\title{
PENGGUNAAN BLANKO AKTA PEJABAT PEMBUAT AKTA TANAH DENGAN DITERBITKANNYA PERATURAN KEPALA BADAN PERTANAHAN NASIONAL NOMOR 8 TAHUN 2012
}

\author{
Oleh \\ Ni Luh Putu Swandewi*, Prof. R.A. Retno Murni, SH.,MH.,Ph.D,**, \\ Dr. Ni Ketut Supasti Dharmawan.,SH.,M.Hum.,LLM** \\ Magister Kenotariatan Universitas Udayana \\ E-mail:info@aridewicollection.com
}

\section{ABSTRACT
THE USE OF THE FORMS OF THE LAND DEED OFFICIAL BY THE ISSUANCE OF THE REGULATION OF THE HEAD OF NATIONAL LANDS AGENCY NUMBER 8 OF 2012

\begin{abstract}
One action of realizing the objective of the enactment of the Basic Agrarian Law is the implementation of land registration by using a Land Deed Official certificates as proof of registration of land. The existence of the certificate forms of the Land Deed Official regulated by the Regulation of the Head of National Land Agency Number 3 of 1997 which was then amended by the Regulation of the Head of National Land Agency Number 8 of 2012, both of them regulate about the Land Deed Official certificate using the land certificate forms. The legal consequences of the abovementioned fact raises questions of the followings: What is the legal standing of the land certificate forms issued by a Land Deed Official under the Regulation of the Head of National Land Agency Number 3 of 1997 which has been used by a Land Deed Official as an evidence of transfer of registration of land rights in the Land Affairs Office after the date of March 31, 2013 by the enactment of the Regulation of the Head of National Land Agency Number 8 of 2012 and what efforts should be taken by the Land Deed Officials in the event that the certificate forms of the Land Deed Official issued under the Regulation of the Head of National Land Agency Number 3 of 1997 is not acceptable as an evidence of transfer of registration of land rights after the enactment of the Regulation of the Head of National Land Agency Number 8 of 2012.

The study is an empirical legal research, examining the gap between the theories (das solen) with the practices (das sein) in which in the Head of National Land Agency Regulation Number 8 of 2012 Article II point 1 letter a, stipulates that a land certificate form of the National Land Agency (BPN) can still be used. Whereas, in the letter $b$ states that the land certificate forms of the National Land Agency which are no longer being used, shall be returned. In practice, in the Land Deed Official office, the use of a land certificate form of the Land Deed Official issued under the Regulation of the Head of National Land Agency Number 3 of 1997 cannot be accepted in the Agrarian Office. The data and the data sources of this empirical legal research are primary, secondary and tertiary data.

The findings of the study indicate the legal standing of the certificate forms of the Land Deed Official issued under the Regulation of the Head of National Land Agency Number 3 of 1997 after the date of 31 March 2013 by law (de jure) is no longer considered as the certificate of the Land Deed Official, but as the evidence of the legal acts set forth therein as the perfect evidence. On the other hand, in practice, the certificate cannot be used as registration evidence by the Agrarian Office, and the solution is to summon the parties to re-sign.
\end{abstract}

Keywords: blank land deed, Land Deed Official, land registration

\section{B A B I PENDAHULUAN}

\subsection{Latar Belakang}

Undang-Undang Nomor 5 Tahun 1960 tentang Peraturan Dasar Pokok-Pokok Agraria diundangkan pada tanggal 24 September 1960 dalam Lembaran Negara Republik Indonesia Tahun 1960 Nomor 104 dan dalam Tambahan
Lembaran Negara Republik Indonesia Nomor 2043 (selanjutnya disebut UUPA). UUPA mempunyai tujuan pokok : (a) meletakan dasar bagi penyusunan hukum agraria nasional, yang akan merupakan alat untuk membawakan dalam rangka masyarakat yang adil dan makmur; (b) meletakan dasar-dasar untuk mengadakan kesatuan dan kesederhanaan dalam hukum 
pertanahan; (c) meletakan dasar-dasar untuk memberikan kepastian hukum mengenai hak-hak atas tanah bagi rakyat seluruhnya, maka negara berkewajiban untuk memberi jaminan kepastian hukum kepada seluruh warga negara mengenai hak-hak atas tanah sekaligus pula memberi perlindungan hukum terhadap pemilikan maupun menguasaan hak-hak atas tanahnya tersebut.

Pendaftaran tanah merupakan perbuatan hukum yang dilakukan dengan tujuan, salah satunya, untuk memperoleh tanda bukti yang sah atas pemilikan tanah yaitu sertipikat. Sertipikat merupakan tanda bukti yang kuat, sekalipun bukan tanda bukti yang mutlak, artinya bahwa segala keterangan yang terkandung di dalam sertipikat mengandung kekuatan hukum dan harus diterima sebagai keterangan yang benar selama tidak ada alat pembuktian yang membuktikan sebaliknya. ${ }^{1}$ Ketentuan Pasal 23, Pasal 32 dan Pasal 38 UUPA diarahkan kepada segenap warga masyarakat agar melaksanakan pendaftaran hakhak atas tanahnya guna tercapainya tujuan perlindungan maupun kepastian hukum yang diberikan oleh negara terhadap hak-hak atas tanah tersebut

PPAT merupakan pejabat umum yang menjadi mitra dalam pengelolaan bidang pertanahan di Indonesia, terutama dalam kegiatan pendaftaran tanah, membantu Badan Pertanahan Nasional (selanjutnya disebut BPN) dalam menguatkan atau mengukuhkan subjek hak yang bersangkutan yang dituangkan dalam suatu akta otentik. Secara normatif hal tersebut dapat dilihat dalam Pasal 37 ayat (1) PP Nomor 24/1997 yang menentukan bahwa, peralihan hak atas tanah dan hak atas satuan rumah susun melalui jual beli, tukar menukar, hibah, pemasukan dalam perusahaan dan perbuatan hukum pemindahan hak lainnya, kecuali pemindahan hak melalui

${ }^{1}$ Adrian Sutedi, 2010, Peralihan Hak Atas Tanah dan Pendaftarannya, Cet. IV, Sinar Grafika, Jakarta, (selanjutnya disingkat Adrian Sutedi I), hal. 113. lelang hanya dapat didaftarkan jika dibuktikan dengan akta yang dibuat oleh PPAT yang berwenang menurut peraturan perundangundangan yang berlaku. Demikian juga dalam Pasal 1 angka 1 Peraturan Pemerintah Nomor 37 Tahun 1998 Tentang Peraturan Jabatan Pejabat Pembuat Akta Tanah yang diundangkan dalam Lembaran Negara Republik Indonesia Tahun 1998 Nomor 52 dan Tambahan Lembaran Negara Republik Indonesia Nomor 3746 (selanjutnya disebut PP Nomor 37/1998), yang menentukan PPAT adalah pejabat umum yang diberi wewenang untuk membuat akta-akta otentik mengenai perbuatan hukum tertentu mengenai hak atas tanah atau hak milik satuan rumah susun atau membuat alat bukti mengenai perbuatan hukum tertentu mengenai hak atas tanah yang akan dijadikan dasar pendaftarannya.

Diterbitkannya Peraturan Kepala Badan Pertanahan Nasional Nomor 8 Tahun 2012 tentang Perubahan Atas Peraturan Menteri Agraria/Kepala Badan Pertanahan Nasional No. 3 Tahun 1997 tentang Peraturan Pelaksanaan Peraturan Pemerintah No. 24 Tahun 1997 tentang Pendaftaran tanah, (selanjutnya disebut Perkabadan Nomor 8/2012 ) menimbulkan kesenjangan antara das solen (teori) dan das sein (praktek) terkait pendaftaran tanah. Persoalan yang timbul akibat terbitnya Perkabadan Nomor 8/2012 tersebut adalah adanya ketentuan Pasal II angka 1 huruf a dan b. Hal tersebut sangat logis sebab tidak ada alat lain selain akta (blanko) yang dapat digunakan oleh PPAT untuk melegalkan perbuatan-perbuatan hukum pihak-pihak yang dimintakan kapadanya untuk dibuat dalam suatu akta otentik sebelum tanggal 31 Maret 2013 tersebut. Permasalahan terjadi ketika blanko akta tersebut dijadikan alat pendaftaran peralihan hak atas tanah pada Kantor Pertanahan setempat dimana letak tanah berada setelah tanggal 31 Maret 2013. Sebab pihak Kantor Pertanahan menganggap akta tersebut tidak berlaku, karena 
blanko akta hanya dapat digunakan sampai dengan tanggal 31 Maret 2013. Sehingga terjadi inkonsistensi penerapan aturan ketentuan "dapat digunakan" antara kenyataan yang terjadi dengan yang diharapkan/dicita-citakan terhadap keberadaan akta PPAT sebagai akta otentik.

\subsection{Rumusan Masalah}

Berdasarkan latar belakang yang telah diuraikan diatas, adapun rumusan yang dapat ditarik dalam penulisan ini yaitu:

1. Bagaimanakah kedudukan hukum blanko akta PPAT berdasarkan Perkabadan Nomor 3/1997 yang telah digunakan oleh PPAT sebagai alat bukti pendaftaran peralihan hak atas tanah pada Kantor Pertanahan setelah tanggal 31 Maret 2013 berdasarkan Perkabadan Nomor $8 / 2012$ ?

2. Apakah upaya yang dilakukan oleh PPAT dalam hal blanko akta PPAT berdasarkan Perkabadan Nomor 3/1997 tidak diterima oleh Kantor Pertanahan sebagai alat pendaftaran peralihan hak atas tanah setelah diterbitkannya Perkabadan Nomor 8/2012?

\subsection{Tujuan Penelitian}

Penelitian ini dilakukan dengan maksud untuk mencapai tujuan yang bersifat umum dan khusus sebagai berikut:

\section{a. Tujuan Umum}

Tujuan umum dari penelitan ini yaitu untuk pengembangan ilmu hukum terkait paradigma Science as a process (ilmu sebagai proses). Dengan paradigma ini, ilmu hukum tidak akan mandek dalam penggalian atas kebenaran, khususnya terkait dengan materi penggunaan blanko akta PPAT dengan diterbitkannya Perkabadan Nomor 8/2012.

\section{b. Tujuan Khusus}

Adapun yang menjadi tujuan khusus dalam penelitian ini sesuai permasalahan yang dibahas adalah :

1). Untuk mendeskripsikan dan menganalisa secara mendalam tentang kedudukan hukum blanko akta PPAT berdasarkan Perkabadan Nomor 3/1997 yang telah digunakan oleh PPAT sebagai alat bukti pendaftaran peralihan hak atas tanah pada Kantor Pertanahan setelah tanggal 31 Maret 2013 berdasarkan Perkabadan Nomor 8/2012?

2). Untuk mendeskripsikan dan menganalisa secara mendalam tentang upaya yang dilakukan oleh PPAT dalam hal blanko akta PPAT berdasarkan Perkabadan No. 3/1997 tidak diterima sebagai alat pendaftaran peralihan hak atas tanah setelah diterbitkannya Perkabadan No. 8/2012?

\subsection{Manfaat Penelitian}

\section{a. Manfaat Teoritis}

Manfaat teoritis yang diharapkan dapat dicapai dalam penelitian ini yaitu untuk pengembangan ilmu hukum dan memberikan bahan informasi yang berguna kepada masyarakat mengenai Penggunaan Blanko Akta PPAT Dengan Diterbitkannya Peraturan Kepala Badan Pertanahan Nasional Nomor 8 Tahun 2012

\section{b. Manfaat Praktis}

Adapun manfaat praktis yang diharapkan dapat dicapai dalam penelitian tesis ini yaitu sebagai berikut:

\section{1) Manfaat bagi Pemerintah}

Hasil penelitian ini diharapkan bermanfaat sebagai informasi bagi kalangan PPAT dan juga pegawai kantor BPN. Informasi yang dimaksudkan adalah untuk tidak terjadi sengketa dalam menangani PPAT yang masih menggunakan blanko akta sesuai dengan Perkabadan Nomor 3/1997 tentang Ketentuan 
Pelaksanaan Peraturan Pemerintah Nomor 24/1997 tentang Pendaftaran Tanah dengan dikeluarkannya Perkabadan Nomor 8/2012.

2) Manfaat bagi masyarakat

Penelitian ini diharapkan dapat menambah pengetahuan dan referensi bagi rekan mahasiswa mengenai penggunaan blanko akta. Selain itu juga agar masyarakat mengetahui pengaturan hukum PPAT dalam membuat akta tanah setelah ditetapkannya Perkabadan Nomor $8 / 2012$.

3) Manfaat bagi Penulis

Bagi penulis penelitian ini diharapkan dapat bermanfaat memberikan tambahan pengetahuan dalam memahami pelaksanaan Keputusan Kepala BPN. Manfaat lain bagi penulis yaitu untuk mengetahui penggunaan dari blanko akta PPAT berdasarkan Perkabadan Nomor 8/2012.

\subsection{Landasan Teoritis}

Adapun asas dan teori-teori yang digunakan sebagai pisau analisis dalam penelitian ini adalah :

1. Teori Kepastian Hukum.

Kepastian hukum secara normatif adalah ketika suatu peraturan dibuat dan diundangkan secara pasti karena mengatur secara jelas dan logis. Jelas dalam artian tidak menimbulkan makna ganda (multi-tafsir) dan logis dalam artian ia menjadi suatu sistem norma dengan norma lain sehingga tidak berbenturan.

2. Teori Keberlakuan Hukum

Kekuatan berlakunya undangundang didalam memberikan jaminan keadilan, kepastian hukum dan kemanfaatan bagi warganegara dapat dijelaskan dalam tiga keberlakuan, antara lain keberlakuan berlaku filosofis, kekuatan berlaku yuridis dan kekuatan berlaku sosiologis.

3. Teori Tanggung Jawab
Ada dua istilah yang menunjuk pada pertanggungjawaban dalam kamus hukum, yaitu liability dan responsibility. Liability merupakan istilah hukum yang luas yang menunjuk hampir semua karakter risiko atau tanggung jawab, yang pasti, yang bergantung atau yang mungkin meliputi semua karakter hak dan kewajiban secara aktual atau potensial seperti kerugian, ancaman, kajahatan, biaya atau kondisi yang menciptakan tugas untuk melaksanakan undang-undang. Responsibility berarti hal yang dapat dipertanggungjawabkan atas suatu kewajiban, dan termasuk putusan, ketrampilan, kemampuan dan kecakapan meliputi juga kewajiban bertanggung jawab atas undang-undang yang dilaksanakan. ${ }^{2}$

\subsection{Metode Penelitian}

a. Jenis Penelitian

Jenis penelitian yang digunakan adalah penelitian hukum empiris. Peneltian hukum empiris adalah penelitian mengenai pemberlakuan atau implementasi ketentuan hukum normatif secara in action pada setiap peristiwa hukum tertentu yang terjadi dalam masyarakat. ${ }^{3}$

\section{b. Sifat Peneletian}

Sifat penelitian dalam penulisan karya ilmiah ini bersifat deskriptif. karena ingin menggambarkan kenyataan yang terjadi.

c. Data dan Sumber Data

Dalam penelitian hukum ini data yang digunakan adalah data drimer (lapangan) dan data dekunder (kepustakaan )

${ }^{2}$ Busyra Azheri, 2012, Corporate Social Responsibility, Cet.II, RajaGrafindo Persada, Jakarta, hal. 86.

${ }^{3}$ Abdulkadir Muhammad, 2004, Hukum dan Peneltian Hukum, PT. Citra Aditya Bakti, Bandung, hal. 134. 
d. Teknik Penentuan Sampel Peneltitian

Adapun lokasi Penelitian dalam penyusunan penelitian ini pada Kantor PPAT Kotamadya Denpasar, Kabupaten Badung, Kabupaten Gianyar dan Kabupaten Klungkung, Provinsi Bali. Dalam Penelitian ini metode sampel yang digunakan adalah sampel secara Non Random Sampling. Populasi yang dipilih menjadi sampel setelah sebelumnya dipilih dan direncanakan oleh peneliti karena populasi ini bersifat heterogen, dimana setiap populasi tidak semuanya dapat mewakili seluruh unit populasi ${ }^{4}$

e. Teknik Pengumpulan Data

Teknik pengumpulan data primer yang dipergunakan dalam penelitian ini adalah dengan metode wawancara Teknik pengumpulan data sekunder dalam penelitian ini menggunakan teknik studi dokumen.

f. Teknik Pengolahan Data

Pengolahan data adalah kegiatan merapikan data hasil pengumpulan data di lapangan sehingga siap pakai untuk dianalisa. ${ }^{5}$ Setelah data dikumpulkan kemudian data diolah secara kualitatif.

\section{g. Teknik Analisis Data}

Dalam mengalisa data, setelah data terkumpul maka langkah penting selanjutnya adalah analisis data. ${ }^{6}$ Analisis data yang dipergunakan dalam peneltian ini adalah analisis deskriptif

\section{BA B I I \\ PEMBAHASAN}

\section{Kedudukan Hukum Blanko Akta PPAT Sebagai Alat Pendaftaran}

${ }^{4}$ Amiruddin dan Zainal Asikin, 2010, Pengantar Metode Penelitian Hukum, Raja Grafindo Persada, Jakarta, hal. 98.

${ }^{5}$ Bambang Waluyo, 2008, Peneltian Hukum dalam Praktek, Sinar Grafika, Jakarta, hal.72.

${ }^{6}$ Bambang Waluyo, op.cit, hal. 19.
Peralihan Hak Atas Tanah Setelah terbitnya Perkabadan Nomor $8 / 2012$

Perkabadan Nomor $3 / 1997$ merupakan salah satu peraturan pelaksanaan yang bersifat teknis, karena menjadi peraturan yang mendasari lahirnya akta PPAT dalam bentuk blanko yang dibuat baik bentuk maupun isinya ditentukan sepihak oleh pemerintah dalam hal ini Badan Pertanahan Nasional (BPN) dalam rangka penyelenggaraan pendaftaran tanah sebagaimana diamanatkan oleh UUPA Pasal 19, selain peraturan pemerintah tentang pendaftaran tanah itu sendiri dan peraturan pemerintah tentang Pejabat Pembuat Akta Tanah. Sebab, UUPA yang merupakan peraturan dasar yang mengatur penguasaan, pemilikan, peruntukkan, penggunaan dan pengendalian pemanfatan tanah bertujuan terselenggaranya pengelolaan dan pemanfaatan tanah untuk sebesarbesarnya kemakmuran rakyat serta menjamin kepastian hak atas tanah, yang menjadi dasar utama dalam rangka kepastian hukum pemilikan tanah. ${ }^{7}$ Dalam rangkaian pendaftaran tanah, secara de yure sertipikat hak milik atas tanah merupakan hasil akhir dari pendaftaran tanah yang berfungsi sebagai alat bukti yang kuat tentang pemilikan hak-hak atas tanah.

Sejalan dengan paparan di atas, selanjutnya dibahas perihal keberadaan blanko akta PPAT setelah diundangkannya Perkabadan Nomor 8/2012. Peraturan tersebut berisi 2

${ }^{7}$ Muchtar Wahid, 2008, Memaknai Kepastian Hukum Hak Milik Atas Tanah, Republika, Jakarta, hal. 67. 
(dua) pasal, yaitu Pasal I dan Pasal II. Dalam Pasal I diatur tentang perubahan ketentuan Pasal 96 Perkabadan Nomor 3/1997, yang menentukan bahwa:

1. Ketentuan pada ayat (2) dihapus;

2. Ketentuan pada ayat (3) diubah; dan

3. Sesudah ayat (3) ditambah 2 (dua ) ayat, yaitu ayat (4) dan ayat (5);

Makna Perkabadan Nomor 8/2012 dilihat dari sisi keberadaan akta PPAT, sebagai upaya pemerintah untuk menjadikannya sebagai dasar hukum tentang bentuk akta PPAT agar lebih mendekati terpenuhinya norma hukum tentang keotentikan suatu akta pejabat umum sebagaimana termaktub dalam Pasal 1868 KHPerdata, karena akta PPAT sebagai produk hukum PPAT, dengan diberlakukannya peraturan tersebut, maka terhitung mulai tahun 2013 penyiapan dan pembuatan akta PPAT sudah dapat dilakukan sendiri oleh Pejabat Pembuat Akta Tanah, Pejabat Pembuat Akta Tanah Pengganti, Pejabat Pembuat Akta Tanah Sementara, dan Pejabat Pembuat Akta Tanah Khusus. Sehingga berdasarkan peraturan tersebut akta PPAT tidak lagi diharuskan menggunakan blanko akta yang dicetak/dibuat oleh BPN dalam bentuk formulir/blanko akta PPAT sebagaimana ketentuan sebelumnya berdasarkan Perkabadan Nomor 3/1997.

Secara operasional penyelenggaraan pendaftaran tanah dilakukan oleh Kantor Pertanahan Seksi Pendaftaran Tanah yang terdapat pada setiap Daerah Tingkat II Kabupaten atau Kota dimana letak tanah tersebut berada. Salah satu bentuk kegiatan pendaftaran tanah, adalah proses penyerahan hak dalam jual beli tanah dilakukan oleh BPN dengan proses pencoretan di dalam sertipikat dari pemilik (penjual) kepada penerima hak dalam hal ini pembeli yang biasa dikenal dengan yuridis lavering. ${ }^{8}$

Pemberian jaminan kepastian hukum dibidang pertanahan pertamatama memerlukan tersedianya perangkat hukum yang tertulis, lengkap dan jelas yang dilaksanakan secara konsisten sesuai dengan jiwa dan isi ketentuanketentuannya. Dalam menghadapi kasus kasus konkret, diperlukan juga terselenggaranya pendaftaran tanah yang memungkinkan bagi para pemegang hak atas tanah untuk dengan mudah membuktikan haknya atas tanah yang dikuasainya. Bagi para pihak yang berkepentingan seperti calon pembeli dan calon kreditor, untuk memperoleh keterangan yang diperlukan mengenai tanah yang menjadi objek perbuatan hukum yang akan dilakukan. Bagi pemerintah untuk melaksanakan kebijaksanaan pertanahan. ${ }^{9}$ Diselenggarakannya pendaftaran tanah membuat para pihak yang bersangkutan dapat dengan mudah mengetahui status atau kedudukan hukum dari pada tanahtanah tertentu yang dihadapinya, letak, luas dan batas-batas, siapa yang mempunyai dan beban-beban apa yang ada di atasnya. ${ }^{10}$ Akta PPAT adalah merupakan produk hukum dari pejabat umum PPAT. Keberadaan akta PPAT tersebut dalam prakteknya berupa

${ }^{8}$ Supriadi, 2008, Hukum Agraria, Sinar Grafika, Jakarta, hal. 152.

${ }^{9}$ Soedharyo Soimin, 2004, Status Hak dan Pembebasan Tanah, Cet II, Sinar Grafika, Jakarta, hal. 159.

${ }^{10}$ M. Yahya Harahap, 2003, Kedudukan Kewenangan dan Acara Peradilan, Sinar Grafika, Jakarta, hal. 82. 
blanko akta PPAT yang semula pengaturannya berdasarkan Perkabadan Nomor 3/1997 sebagai peraturan pelaksana dari PP Nomor 24/1997 dan selanjutnya diatur berdasarkan Perkabadan Nomor 8/2012 sebagi pengganti dari Perkabadan Nomor 3/1997 tersebut. Kedudukan hukum akta PPAT jika dilihat dari sisi fungsinya selain sebagai alat bukti tertulis yang otentik tentang perbuatan-perbuatan hukum atas tanah bagi pihak-pihak yang membuatnya, juga sebagai syarat atau sebagai dasar pendaftaran peralihan hak atas tanahnya. Dalam hal blanko akta PPAT berdasarkan Perkabadan Nomor 3/1997 tidak dapat digunakan sebagai alat pendaftaran peralihan hak atas tanah setelah tanggal 31 Maret akan tetapi dapat berkedudukan sebagai alat bukti sebagai akta otentik tentang perbuatan-perbuatan hukum atas tanah di dalamnya.

2. Upaya Yang Dilakukan PPAT Dalam Hal Blanko Akta PPAT Berdasarkan Perkabadan Nomor 3/1997 Tidak Dapat Diterima Sebagai Alat Pendaftaran Berdasarkan Perkabadan Nomor 8/2012

Tugas pokok PPAT adalah melaksanakan sebagian kegiatan pendaftaran tanah dengan membuat akta sebagai bukti telah dilakukannya perbuatan-perbuatan hukum tertentu baik sebagai peralihan ataupun sebagai pembebanan hak atas tanah sebagaimana dimaksudkan oleh PP Nomor 24/1997. Dalam tugas pokoknya seperti itu menempatkan PPAT sebagai bagian dari sub sistem pendaftaran tanah di Indonesia, sehingga kedudukannya merupakan salah satu bagian penting dari kegiatan pendaftaran tanah.
Pemerintah untuk mengatasi segala hambatan yang telah terjadi dengan penggunaan blanko akta PPAT yang diterbitkan oleh BPN menetapkan Perkabadan Nomor 8/2012 berdasarkan peraturan ini dapat diketahui bahwa blanko akta PPAT dibuat dan disiapkan sendiri oleh PPAT bersangkutan dengan format yang ditetapkan oleh BPN. Dengan terbitnya Perkabadan Nomor 8/2012 ini maka blanko akta PPAT yang semula dicetak oleh BPN menjadi tidak berlaku dan tidak dapat dipergunakan lagi dalam peralihan hak karena dalam Perkabadan Nomor 8/2012 ini ditentukan bahwa PPAT sendiri yang mempersiapkan akta yang akan dipergunakan untuk peralihan hak tersebut.

Munculnya Perkabadan Nomor $8 / 2012$ ini tentunya memudahkan kinerja PPAT untuk melakukan pekerjaannya, namun pada masa transisi dari saat ditetapkan hingga berlakunya Perkabadan ini, sempat menimbulkan polemik di kalangan PPAT itu sendiri. Karena banyak PPAT yang masih menyimpan blanko Perkabadan Nomor 3/1997, yang dengan dikeluarkannya Perkabadan Nomor $8 / 2012$ ini, blanko tersebut menjadi tidak dapat dipergunakan lagi. Aturan yang tercantum dalam Perkabadan Nomor $8 / 2012$ ini hanya menyatakan bahwa bagi PPAT yang tidak menggunakan wajib mengembalikan blanko akta tersebut. Bahkan tidak sedikit PPAT yang penggunaan blanko akta terbitan Perkabadan Nomor 3/1997 tersebut tidak diterima di Kantor Pertanahan setempat. Dalam Perkabadan Nomor 8/2012 dapat diketahui bahwa blanko 
akta terbitan BPN masih dapat digunakan hingga tanggal 31 Maret 2013, sedangkan sosialisasi mengenai penerapan Perkabadan Nomor 8/2012 tersebut baru dilaksanakan tanggal 1 April 2013. Tentunya hal ini mengakibatkan banyak PPAT masih menggunakan blanko terbitan Perkabadan Nomor 3/1997 yang kemudian tidak dapat diterima penggunaanya di Kantor Pertanahan setempat. Sebagaimana dikatakan oleh I Nyoman Alit Puspadma, PPAT di Kabupaten Badung, pada wawancara tanggal 9 Januari 2014 mengatakan bahwa setelah ditetapkannya Perkabadan Nomor 8/2012 ini masih menggunakan blanko akta PPAT Perkabadan Nomor 3/1997 dan Kantor Pertanahan setempat tidak dapat lagi menerima penggunaanya sejak tanggal 31 Maret 2013, padahal sosialisasi atas penggunaan Perkabadan Nomor 8/2012 ini baru dilaksanakan tanggal 1 April 2013.

Pendaftaran peralihan Hak tidak dapat dilakukan di BPN karena tidak bisa lagi menggunakan blanko akta PPAT Perkabadan Nomor 3/1997. Hal ini tentu saja mengganggu jalannya proses pemberian jaminan kepastian hukum bagi masyarakat. Upaya yang dilakukan oleh PPAT terhadap hal tersebut adalah melakukan pemanggilan ulang terhadap para pihak yang melakukan perbuatan hukum yang dituangkan dalam akta PPAT yang masih menggunakan blanko akta PPAT terbitan Perkabadan Nomor 3/1997 ke blanko akta PPAT berdasarkan Perkabadan No. 8/2012. Dengan hal tersebut maka proses pendaftaran peralihan hak atas pada kantor pertanahan bisa terlaksana.

\section{B A B III \\ PENUTUP}

\subsection{Kesimpulan}

Berdasarkan pembahasan yang telah diuraikan diatas, maka dapatlah ditarik kesimpulan sebagai berikut:

1. Kedudukan blanko akta PPAT berdasarkan Perkabadan Nomor 3/1997 setelah tanggal 31 maret 2013 secara de jure bukanlah sebagai bentuk akta PPAT, akan tetapi sebagai alat bukti tentang perbuatanperbuatan hukum yang termaktub didalam akta tersebut, merupakan alat bukti yang sempurna untuk membuktikan tentang kebenaran perbuatan-perbuatan hukum yang dimaksud. Sementara itu secara de facto oleh kantor pertanahan (BPN) akta tersebut tidak dapat digunakan sebagai alat pendaftaran peralihan hak atas tanah.

2. Upaya yang dilakukan oleh PPAT dalam hal akta PPAT berdasarkan Perkabadan Nomor 3/1997 tidak dapat diterima sebagai alat pendaftaran peralihan hak atas tanah adalah memanggil kembali para pihak untuk menandatangani ulang akta sesuai dengan Perkabadan Nomor 8/2012 dan memberikan sosialisasi atas pemberlakuan peraturan tersebut.

\subsection{Saran}

Adapun saran yang dapat diberikan atas permasalahan yang diangkat dalam penelitian tesis ini yaitu:

1. Bagi Pemerintah untuk meniadakan kesenjangan antara das solen dan das sein akibat memberlakukan 
suatu peraturan perundangundangan yang baru dibidang pertanahan oleh pemerintah, maka disarankan agar dalam melakukan penggantian terhadap suatu peraturan perundang-undangan dan memberlakukan peraturaan perundang-undangan yang bertidak serta merta mengakibatkan suatu produk hukum yang dibuat berdasarkan peraturan perundangundangan yang diganti tersebut tidak berlaku, mengingat kedudukan akta PPAT sebagai alat pendaftaran peralihan hak sangat tergantung dari persyaratan-persyaratan yang bersifat komplementer/pelengkap dan hal tersebut dapat berakibat pada hilangnya hak-hak atas tanah seseorang.

Bagi PPAT dengan diberikan kewenangan untuk membuat akta sendiri, supaya memperhatikan segala ketentuan yang ada berdasarkan Perkabadan Nomor 8/2012 agar substansi akta dapat mencakup semua informasi yang diperkulan oleh kantor pertanahan dalam rangka pendaftaran peralihan hak atas tanah dan pemeliharaan data tanah.

\section{DAFTAR PUSTAKA}

\section{BUKU}

Azheri , Busyra, 2012, Corporate Social Responsibility, Cet.II, Raja Grafindo Persada, Jakarta.

Amirudin dan Zainal Asikin, 2010, Pengantar Metode Penelitian Hukum, Raja Grafindo Persada, Jakarta.

Harahap, M. Yahya, 2003, Kedudukan Kewenangan dan Acara Peradilan, Sinar Grafika, Jakarta.

Muhammad, Abdulkadir, 2004, Hukum dan Penelitian Hukum, PT. Citra Aditya Bakti, Bandung.

Sutedi, Adrian, 2010, Peralihan Hak Atas Tanah dan Pendaftarannya, Cet. IV, Sinar Grafika, Jakarta, (selanjutnya disingkat Adrian Sutedi I)

Supriadi, 2008, Hukum Agraria, Sinar Grafika, Jakarta.

Soimin, Soedharyo, 2004, Status Hak dan Pembebasan Tanah, Cet. II, Sinar Grafika, Jakarta.

Watt, Robert, 2001, Concise Legal Research, The Federation Press, Leinchrdt, NSW.

Wahid, Muchtar, 2008, Memaknai Kepastian Hukum Hak Milik Atas Tanah, Republika, Jakarta.

Waluyo, Bambang, 2008, Penelitian Hukum dalam Praktek, Sinar Grafika, Jakarta.

\section{PERATURAN PERUNDANG-UNDANGAN}

Undang-Undang Nomor 5 Tahun 1960 tentang Peraturan Dasar Pokok-pokok Agraria (Lembaran Negara Republik Indonesia Tahun 1985 Nomor 75, Tambahan Lembaran Negara Republik Indonesia Nomor 2043) 
Peraturan Pemerintah Nomor 24 Tahun 1997 tentang Pendaftaran Tanah (Lembaran Negara Republik Indonesia Tahun 1997 Nomor 59, Tambahan Lembaran Negara Republik Nomor 3696)

Peraturan Menteri Negara Agraria/Kepala BPN Nomor 3 Tahun 1997 tentang Ketentuan Pelaksanaan Peraturan Pemerintah Nomor 24 Tahun 1997 tentang Pendaftaran Tanah.

Peraturan Kepala Badan Pertanahan Nasional Nomor 8 Tahun 2012 tentang Perubahan Atas Peraturan Menteri Agraria/Kepala Badan Pertanahan Nasional No. 3 Tahun 1997 tentang Ketentuan Pelaksanaan Peraturan Pemerintah Nomor 24 tahun 1997 tentang Pendaftaran Tanah

$* * * * *$ 